\title{
Administrative capacity and long-term policy making at the Icelandic local level
}

\author{
Eva Marín Hlynsdóttir, Assistant Professor, Faculty of Political Science \\ University of Iceland.
}

\begin{abstract}
Leach and Wilson (2002) identified four key tasks of local government leaders. Building on their initiative, this paper examines the task of developing strategic and policy direction at the Icelandic local level from the viewpoint of the Icelandic mayor. In addition, it explores the administrative capacity of Icelandic local governance. Individuals occupying mayoral positions in Iceland always serve as heads of administration. At times, mayors are council members (political mayors), while other times they are hired based on their professional skills (manager-mayors). The findings suggest that mayors of both types play crucial roles in long-term policy making. However, the study shows that the daily work of manager-mayors is often hindered by fragmentation and lack of specialisation within the administration as well as by the laymen rule upon which the council-committee system is based.
\end{abstract}

Keywords: local government; administrative capacity; long-term policy making.

\section{Introduction}

The institutional structure of local government decision making varies considerably between countries. Nevertheless, local governance is normally a combination of political leadership, administrative leadership and the laymen rule (Mouritzen \& Svara 2002). Leach \& Wilson (2000, 14-16) formulated a model of key tasks of local leaders based mainly on the work of Kotter and Lawrence (1974) and Selznick (1957). These key

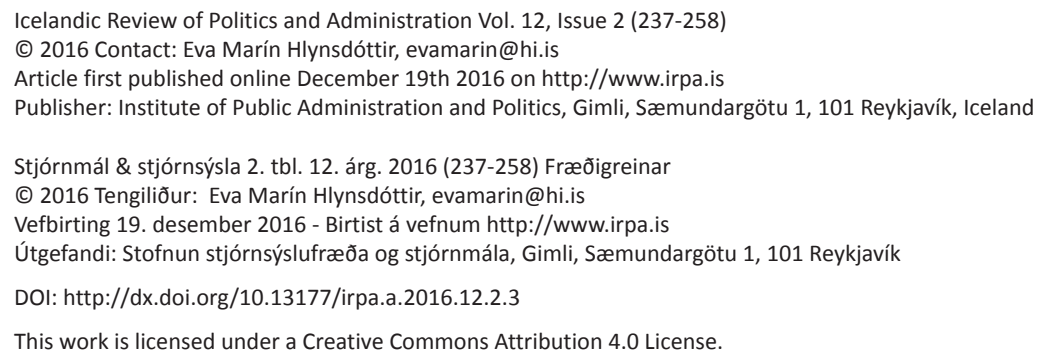


functions involved maintaining cohesiveness, developing strategic and policy direction, representing the local authority in the external world and ensuring task accomplishment. Concepts such as strategic thinking, agenda setting, policy making and budgeting are used to describe various types of decision making within public organisations. Thus, all local government makes strategy. However, there is a fundamental difference between long-term and short-term decision making. The former involves thinking ahead and making decisions for the future in a proactive way, while the latter entails reactive decision making (as in a crisis) (Getimis \& Hlepas 2006; Leach \& Wilson 2000). Overall, research on Icelandic public administration indicates that there is a lack of long-term strategic thinking and that policy making and agenda setting are often more coincidental than deliberate (Árnason, Nordal, \& Ástgeirsdóttir 2010; Sigurgeirsdóttir 2006; Sigurgeirsdóttir 2005). Research findings also suggest that the decision-making process is even less structured at the Icelandic local level than it is at the central level (Kristinsson 2014; Kristinsson 2001).

Furthermore, there is a lively theoretical debate on who should be responsible for strategic thinking and policy making. Some view the political-administrative relationship as a dichotomy in which there should be a clear task division between politicians and the administration, with politicians responsible for decision making and administrators responsible for implementation and daily management of the organisation (Demir 2009; Jacobsen 2009; Mouritzen \& Svara 2002). Others contend that the political-administrative relationship is interactive and overlapping, with unclear boundaries between the roles of politicians and administrators (Stocker Thompson-Fawcett 2014; Zhang \& Feiock 2009; Bergström, Magnusson, \& Ramberg 2008). According to the first viewpoint, politicians should lead the decision-making process, while adherents to the second viewpoint accept administrative leadership within the policy-making process. However, it is also possible to argue that both viewpoints assume that both politicians and administrators have the capacity to fulfil their roles in the policy process.

This paper explores the task of developing strategic and policy direction at the Icelandic local level in relation to the overall administrative capacity of Icelandic local governance. Furthermore, it aims to answer the following questions:

Who is leading the task of developing strategic and policy direction at the Icelandic local level? Based on these findings, what conclusions may be drawn about the administrative capacity of Icelandic local governance?

To deal with these questions the Icelandic mayors role perception in relation to the policy making process is discussed. These findings are then discussed in relation to the overall number of specialised staff within the town halls. In general, the council, the local leaders and the administration are highly interlinked thus when one division is lacking in capacity other divisions of local government is affected. Therefore, lack of leadership capacity within the council is expected to put pressure on the mayors and/or the administration. In a similar manner lack of professional capacity in the administration is expected to affect the council and the mayors negatively. This study is based on the viewpoint of the mayors and therefore it is not possible to draw any conclusions on 
what effects lack of leadership on behalf of the manager-mayor and the political mayor would have on council and the local administration.

The paper is divided into eight sections of which the first concentrates on the theoretical background of the discussion. It then goes on to introducing the data collection in the second section and introducing the Icelandic local government structure in the third section. The fourth section is the first to deal with empirical data as it introduces findings on the number of staff in the town halls. In section five to seven findings on the task of developing strategic and policy direction are introduced with each section dealing with one of the three strands of the task. The eighth and final section discusses the findings.

\section{Strategic decision making and administrative capacity}

Lately leadership has become an extremely desirable quality, something to be cultivated and strived for. There is, however, no general agreement on how to become a leader or how to demonstrate leadership ability (Bergström, Gianoli, \& Rao 2012). Northouse (2013) defines leadership as 'a process whereby an individual influences a group of individuals to achieve a common goal' (p.5). In essence, this definition states that leadership entails a two-dimensional process of control involving leaders as well as followers. The group context is important as leadership must include more than one individual; it is not possible to express leadership in solitude (Northouse 2013; Parry \& Bryman 2006). In the context of Icelandic local government, local leaders may be either administrative leaders, political leaders or both, and they may exercise leadership in a variety of ways. Local leaders who use their influence to set visions and shape the culture or structure of the local authority as well as hiring and firing are all exercising power invested in their role as a leader of that unit (Collinson 2011). It is important to try to balance the discussion on leadership between a contextual or structural approach and a more individual and behavioural approach. Too much emphasis on behaviour may undermine the importance of context and too much emphasis on context makes individuals seem helpless in having any influence over their leadership behaviour (Peele 2005, 192). To distinguish between these different types or variations of leadership Mouritzen \& Svara (2002) argue that governmental systems usually represent some compromise between the three principles or elements of the 'laymen rule', 'political leadership' and 'professionalism'. How each of these elements is represented within the governmental system varies across countries. Mourtizen and Svara also point out that an amateur politician frequently brings enthusiasm and passion while the administration with the manager at the front brings expertise and rationality into local government. Thus, the main argument is that 'to be focused and efficient, governments need professionals who bring distinct perspective and background to government' (Mouritzen and Svara 2002, 53). Previous studies have shown that although there are clear differences between the Icelandic political mayors and manager-mayors both types play a major role as community leaders (Hlynsdóttir 2016a). Thus, this study draws on the example of Leach and Wilson (2002) by viewing leadership behaviour as something exercised by both local politicians as well as local administrators. 
In their seminal work Local Political Leadership, Leach and Wilson (2000) name three components of the task of developing strategic and policy direction: 'core values', 'strategic vision' and 'strategic response'. In their work they pointed out that this task has been growing in importance. As an example Demir and Reddick (2012) point out that local government politicians could use more skills to think strategically and on longterm basis as well as approach policy problems from a broader point of view. Leach and Wilson (2000) used the processes of 'core values', 'strategic vision' and 'strategic response' to identify how involved local leaders were in the task of developing strategic and policy direction. To begin with they point out that 'core values' are most often expressed in documents such as mission statements. Furthermore, they argue that the relevance and usefulness of such documents vary, and they are often ignored after completion. Leach and Wilson pointed out that the scope for leadership is greatest with the second element, 'strategic vision'. Here, the agendas are set, and problems are identified (or ignored). Furthermore, as pointed out by Leach and Wilson, the private interests of politicians or even administrative leaders may influence which issues are addressed and which are not. The third and final element, 'strategic response', relates to how to respond to anticipated or (perhaps more frequently) unanticipated issues. Leach and Wilson described significant variation in how such issues are addressed: '...[T] a major difference between authorities that react to the need to make such choices in a short-term incremental fashion, and those that do so within the framework of an explicit longer-term corporate strategy, which explores the links between such choices' (Leach \& Wilson 2000, 74).

A public organisation may be structured in various ways. As an example, Mintzberg (1983) differentiated between complex and simple structures, suggesting that structures of small organisations tend to be simple. Others take this argument one step further. For example, Randma-Liiv (2002) stated that public organisations in small states face different problems and challenges than do bureaucracies in larger states. She pointed out, in particular, some problematic issues concerning the 'ideal type of bureaucracy':

$[\mathrm{It}]$ is above all a form of organisation dedicated to the concept of rationality, including accountability to political leadership, recruitment based on formal qualifications, career orientation for professionals, specialised and differentiated roles, a well understood and stable hierarchy, well-defined spheres of competence, job security and other appropriate incentives (Randma-Liiv 2002, 386).

Ever since Dahl and Tufte published Size and Democracy (1973), there has been an abundance of literature written about local government size, but social scientists have yet to reach any final verdict on the ideal size for a local authority (Denters et al. 2014; Baldersheim \& Rose 2010; Kjær \& Mouritzen 2003; Newton 1982; Dahl \& Tufte 1973). Dahl and Tufte (1973) argued that size should be measured on two dimensions: citizen effectiveness and system capacity. Citizen effectiveness refers to the extent that citizens 
can control decisions of the polity, while system capacity refers to the capacity of the polity to respond adequately to its citizens. The debate on democracy and efficiency at the local level remains as lively (Denters et al. 2014; Vetter \& Kersting 2003) as it was when Dahl and Tufte introduced their findings. This debate is particularly relevant to research on the Icelandic local government level.

Arguments made on behalf of the Icelandic central government and the Local Government Associations have long been in favour of the 'big is beautiful' argument (Eythórsson 2014). Icelandic researchers have pointed out the problems of having many small municipalities (Kristinsson 2014), highlighting mainly a lack of capacity for service provision and finances as well as possible democratic deficits. Others have emphasised the problems that may follow in the aftermath of an amalgamation of municipalities (Eythórsson 2003). As of yet, there has been only one major study (Ragnarsson 2003) on cooperation projects at the local level in Iceland ${ }^{1}$. In his study Ragnarsson defined the concept of capacity as the number of citizens and the amount of income that a municipality needs to be able to provide its residents with the services they need and want ( $\mathrm{p}$. 14). Another approach to the concept of capacity may be found in Stone $(1993,17)$ as he suggests that 'technical capacity' may be enhanced through technical competence and the training and expertise of administrative staff. Similar emphasis on human resource management is at the heart of Farazmand's $(2004,6)$ discussion on administrative capacity as he points out the necessity of administrative staff to be highly qualified, able and motivated in order to tackle daily management problems as well as the strategic choices of tomorrow. In a similar manner Lundtorp $(2000,25)$ suggests that the administration must be able to demonstrate leadership and handle specialised tasks in a professional way. Thus, using a definition by Polidano $(2000,805)$ administrative capacity is 'the ability of the permanent machinery of government to implement policies, deliver services and provide policy advice to decision-makers.' In the Icelandic context issues related to the capacity of local authorities to provide services effectively and efficiently have been among the main arguments for amalgamation in Iceland in the past few decades (Eythórsson 2014).

Grounded in the above discussion this study views the professional ability of local administration as an important part of administrative capacity. Thus, the number of specialised staff within the town hall may serve as a good indicator of the administrative capacity at the Icelandic local level. This leads to the next section on data collection.

\section{Data collection}

The data used in this paper was collected for a larger project on leadership at the Icelandic local level ${ }^{2}$. The study relied mainly on two sources of data. Firstly, a telephone survey was conducted in December 2011. At that time, there were 76 municipalities in Iceland. One municipality was in the process of being merged into a neighbouring municipality, and another was in the process of hiring a new manager-mayor. These two municipalities were therefore excluded from the survey. The survey questions were based on the questionnaires used in a study on European mayors (Bäck, Heinelt, \& Mag- 
nier 2006, 379) and in the U.Di.T.E study ${ }^{3}$ (Andersson \& Mouritzen 1998, 292). Thus, by basing the questionnaire and interview questions on these previous studies the research design covered both the political aspect of the Icelandic mayors' position as well as the executive role. The second source of data was semi-structured interviews. The lower limit for populations of the targeted municipalities was set at 500 inhabitants. One of the main issues of the study was the interaction between different types of mayors and local administrations. As very small municipalities have a limited administrative capacity, a cap at 500 inhabitants was deemed justifiable. In 2012, there were 50 municipalities with more than 500 inhabitants. For the quantitative and qualitative data to be coherent, only manager-mayors and political mayors who had participated in the first round of data collection were interviewed. The interview session started in April 2012 and lasted until October 2012, by that time six mayors had left office without being interviewed. The final number of participants was 12 political mayors and 32 manager-mayors. The sample covered 88 per cent of the population with a response rate of 100 per cent.

As both types of mayors hold a distinctive and public position of considerable authority, they fall under Odendahl \& Shaw (2002) definition of elites. Moreover, Littig (2009) states that the interviewer is not a neutral participant as the interview represents a special form of a social relationship. More importantly the individual being interviewed is also not a neutral participant as elite interviews 'provide a subjective account of an event or issue' (Richards 1996, 200). Thus, responses in an elite interview are a reflection of the values and thoughts of the interviewee and as such a subjective account of the interviewee's world. Berry (2002) has pointed out some methodological issues to be aware of when interviewing elites. He points out that elites may be prone to exaggeration, which would lead us to ask what they have left out as exaggeration increases the amount of information omitted. Moreover, if they exaggerate what does that mean for their credibility? However, there are ways of addressing these problems. It is import to be prepared and to ask questions about other individuals in the organisation as they may not lessen the role of others by exaggerating their own. It is also helpful to move away from questions as in a conversational type of interview - there is no need for them to be linear (p. 681). Another possible solution is to increase the number of cases or observations (King, Keohane, \& Verba 1994). Thus, by maximising the number of observations or in this case the number of mayors interviewed the more robust the findings become.

\section{The context of Icelandic local governance}

This section discusses the structure of local government in Iceland in order to provide background information on the context of Icelandic local governance. ${ }^{4}$ The Icelandic local government system is a council-committee system in which the highest authority lies with the council. Icelandic council members are in general amateurs with the exception of Reykjavík's city council; it has 15 members who are all professional politicians. The councils of Iceland's other municipalities are populated with between 5-11 politi- 
cians depending on population size $e^{5}$. Out of the 75 municipalities in existence in 2012 , 30 had five council members and 30 had seven council members. Kristinsson (2014) has shown that councils in larger municipalities more often use the lower limit on council membership size. As an example, there are six municipalities with more than 10,000 inhabitants, but only Reykjavík has a 15-member council. It may be added that while Reykjavík has had a 15-member council for the past hundred years ${ }^{6}$, its population has multiplied during that period. According to Kristinsson, this tendency to choose a lower limit makes it easier for established parties to gain a majority in the council and makes it more difficult for new parties to enter the council. Kristinsson also pointed out that where the councils have opted for seven members, the majority has effectively devised a method to prevent new parties from entering the council. Nevertheless, an analysis of municipalities created through amalgamation shows that the councils in these municipalities often use the higher limit. Previous research has shown that this is done mainly to make it easier for citizens of the previously separate municipalities to be represented in the council (Eythórsson, Jóhannesson, \& Hlynsdóttir 2002). In the past few years, there has been a growing concern of increase in turnover within the councils. As an example, 65 per cent of local councilwomen and 52 per cent of councilmen in 2010 had never sat on the council before (Hagstofa Íslands 2010), and an overview of the 2014 local election results revealed similar findings (Hagstofa Íslands 2015). International research findings have shown that professional politicians have lower turnover than amateur politicians (Verhelst, Reynaert, \& Steyvers 2013). A large majority of Icelandic council members are political amateurs in the sense that council membership is not their main occupation or source of income.

The second most important committee after the council itself is the executive committee or executive board, which exists only in municipalities with seven or more council members. The executive board handles the daily operation of the municipality alongside the head of administration. Members of the executive board are appointed from within the council and represent proportionally the council minority and majority. As an example, when the board consists of three individuals, two represent the council majority and one the minority. This situation is irrespective of how many parties are represented in the council. Thus, not all the parties have a representative on the executive board.

Other committees tend to be responsible for their functionally defined areas, but the Local Government Act (no.138/2011) does not provide these committees with any executive powers in their own right. However, this does not prevent other acts from providing these committees with independent functions, such as in child protection services. The members of the committees are often appointed from outside the council on a minority and majority basis. These committee members are not necessarily politically linked with the political majority or minority in the council, and they are often chosen because of alleged expertise. In the past decade, there has been a growing tendency to cut the number of these committees either by merging them or by having the council or the executive board take over their responsibilities. 
Similar to the other Nordic countries, the Icelandic system is monistic since the power of local government is concentrated within the elected council (and its committees). The council and its committees are thus decision makers who exert direct control over the local administration. This stands in direct contrast to a dualistic system in which the head or chief executive of the local administration has executive powers in his/her own right even though the council is seen as the main decision-making body (Wollmann 2004).

There are two main types of local government chief executives. The first type is an individual who is also a member of the council (political mayor) and the second type is an individual who is not a member of the council (manager-mayor). Both types of chief executive play central roles and often possess considerable political and professional capacity (Hlynsdóttir 2016b).

Although the structure of local government has more or less remained the same since 1986, the tasks of Icelandic local government have changed a great deal (Hlynsdóttir 2015). In the early 1990s, Icelandic municipalities were still mainly divided into two categories: rural municipalities with little to no urbanisation on the one hand and villages or towns on the other. The towns and villages had municipal offices consisting of experts and technical staff and had at least to some extent developed hierarchical administrations. Furthermore, the towns were responsible (or voluntarily took responsibility) for tasks such as planning, sewage, waste management, hot and cold water supply and the infrastructure of urban settlement. In addition, they were also responsible for tasks such as the development of day care services in the 1980s. Many of these urban authorities invested heavily in local businesses.

In theory, the agricultural authorities had the same responsibilities as their urban counterparts. Nevertheless, there was almost no planning in these areas as farmland was at the time exempted from planning obligations. There was no sewage or waste management, very little water management and no day care services. Other than farms, local businesses were scarce, and it was rare for rural municipalities to invest in other local businesses, even when they already existed. The local administration found in rural areas consisted typically of a council leader using his home as an office. Thus, at the beginning of the 1990s the share of Icelandic municipalities in the provision of welfare services was much lower than that found in other Nordic countries (Eythórsson 1999, 64).

Since then, Icelandic authorities have more or less followed the international trend of increasing the responsibilities and scope of local government functions (Kuhlmann \& Wollmann 2014). Icelandic municipalities are now responsible for an extensive amount of welfare services, such as social services, primary education, and planning and disability services. Furthermore, all municipalities have by law (LGA no 138/2011) the same responsibilities towards their citizens. As the populations of a large majority of Icelandic municipalities are still relatively small, these reforms have resulted in an extensive network of local authorities working in cooperation in order to provide services to citizens. This leads us to the next section on the number and type of staff employed in the town halls. 


\section{The number of staff in town halls}

One of the main measurements on administrative capacity is the local governments capacity to hire professional and specialised staff into the town hall (Kjær and Mouritzen 2003; Lundtorp 2000). Previous studies have shown that Icelandic local authorities stress professional capacity and skills when hiring manager-mayors (Hlynsdóttir 2016b), less is known about the overall capacity of the local administrative level. In his 2001 study on Icelandic local government, Gunnar Helgi Kristinsson pointed out that size was a crucial factor in defining the structure of local administration. At that time, 74 per cent of all municipalities had no more than 1-3 staff members (including the political or manager-mayor) within the administrative office. It goes without saying that such a small administration has very little capacity to employ support staff or create a formal and structured division of labour. Furthermore, Icelandic councils are very small in comparison to their Nordic counterparts. Thus, while councils in other Nordic countries often function more as local assemblies (Kristinsson 2014), Icelandic councils are usually highly involved in the implementation process, and council members often become involved with detailed administrative work.

During the interviews the mayors were asked to estimate the number of staff in their respective town halls. They were also asked to indicate the job titles of their staff members and whether more than one individual held the same job title. Furthermore, the mayors were asked to limit their response to their immediate staff, thus only employees with offices within the town hall were included. This excludes public employees such as teachers or staff with offices situated outside the town hall itself.

The number of staff working within a given town hall is a good indicator of the administration's professional capacity. Furthermore, investigating the number of staff employed by a town hall also shows the number of personnel under the daily supervision of the mayor. Before discussing the average number of staff in a town hall, it should be pointed out that the standard deviation (SD) is relatively high, which indicates that there are substantial differences in the number of staff members within each group. The reason for this is mainly the extensiveness of inter-municipal cooperation. Within each size group, there are municipalities that have a disproportionally large number of personnel because of the breadth of the services they provide to other municipalities. Similarly, there are municipalities with a disproportionally small administration because they receive services from outside the municipality. Despite their shortcomings, these results give an important indicator of the number as well as the type of staff that municipalities are employing into their immediate surroundings. Table 1 displays the average number of municipal personnel divided into four groups according to population size. 
Table 1. Icelandic mayors' estimation of average number of local government administrative staff $^{7}$

\begin{tabular}{lccc}
\hline Population & Average number of staff & SD & $\mathrm{N}$ \\
\hline $500-999$ & 5 & 1.5 & 14 \\
$1,000-2,499$ & 10 & 3.4 & 13 \\
$2,500-4,999$ & 24 & 7.5 & 9 \\
$5,000-9,999$ & 34 & 7 & 3 \\
\hline Total & 13 & 39 & 39 \\
\hline
\end{tabular}

In the smallest size category (500-999 residents), the average number of staff in town hall was five. It is rare for municipalities in this size category to hire experts to work in the town hall. The staff typically consisted of an office manager, bookkeeper, payroll clerk and property supervisor. Legal, technical or other kinds of administrative support were received through other channels. There were three main types of supporting channels. The first possibility was to receive the service from an institution built on a cooperation scheme (quangos). In such cases, the institution was built on cooperation among several municipalities, but the office was semi-independent (i.e., not in-house). The second type was when municipalities purchased a service from another municipality or a private firm, such as legal assistance. The third possibility was if the Local Government Association provided the services.

The second population size category was 1,000-2,499 residents. Here, the average number of personnel reached 10 individuals. There was a considerable variation within this category, as some of the municipalities had a disproportionally large administration due to having taken over service responsibilities through local government cooperation schemes. In this category, the number of core staff (e.g., bookkeepers and clerks) increased, and experts such as engineers, planners or social workers began to appear. In this size category, it was also common to have divisions within the administration, even though in some cases the units only consisted of one or two employees. Supporting staff such as legal advisers were still non-existent in this category.

The third category consisted of municipalities in the size group of 2,500-4,999. On average, the municipalities in this group had 24 staff members in the town hall. These municipalities were more likely to be the service providers in cooperation schemes and thus had all or many of the experts in-house. They relied on different divisions in their organisation and often had numerous staff members in each. Moreover, support staffs such as lawyers and supporting experts were rarely found in this category.

The fourth category included municipalities with 5,000-9,999 inhabitants. Municipalities in this category had, on average, 34 employees in the town hall. These municipalities were similar in many ways to those in the third category, except in the number of personnel. These municipalities usually had more than one person with similar knowledge or expertise and were thus not as reliant on individuals. 
Municipalities with over 10,000 inhabitants were not included in the table. Overall, the structure of the administration was much more complicated and larger than in the smaller municipalities. The most significant differences were in the presence of support staff, as these municipalities had numerous lawyers and technical experts in addition to various experts and support staff.

In addition, the Local Government Association runs wide-ranging services for the municipalities. Up to 76 per cent of the respondents in the 2011 mayor survey communicated with the Association 1-3 times a month and 15 per cent were in weekly contact. The Local Government Association is thus an essential provider of information and administrative support for both types of local leaders.

The number of specialised staff within the town hall has grown within all size categories since Kristinsson conducted his study in 2001. Although the analysis shows a clear connection between population size and number of specialised staff the correlation is not as clear cut as one would expect. The extensiveness of inter-municipal cooperation schemes is complicating the matter as it disproportionally boosts the capacity of one local authority while shrinking it in another. Nevertheless, the number of and type of supporting staff within the town hall indicates that the local administration may not always be equipped to provide the council and the local leaders with the support they need in their policy-making roles.

\section{Policy making at the local level: core values}

Theories on the political-administrative relationship suggest that the prerequisite for administrative staff to be able to do their job efficiently, politicians need to set a clear course (Frederickson \& Smith 2003; Leach \& Wilson 2000; Svara 1990). Thus, the mayors were asked to estimate to what extent unclear goals in policy making had had a negative effect on their daily work.

Table 2. Unclear goals in local policy making and negative effect on daily work

\begin{tabular}{cccccc}
\hline $\begin{array}{c}\text { To a very } \\
\text { great extent }\end{array}$ & $\begin{array}{c}\text { To a } \\
\text { great extent }\end{array}$ & $\begin{array}{c}\text { To } \\
\text { some extent }\end{array}$ & $\begin{array}{c}\text { To a } \\
\text { little extent }\end{array}$ & Not at all & N \\
\hline $4(5 \%)$ & $7(9 \%)$ & $17(23 \%)$ & $36(49 \%)$ & $10(14 \%)$ & $74(100 \%)$ \\
\hline
\end{tabular}

As shown in Table 2 around 23 per cent had experienced some negative impact, while 15 per cent had felt a great or very great negative influence due to a lack of goals in their day-to-day work. When position is added to the analysis, a clear trend emerges, as 82 per cent of political mayors had not experienced any negative effects because of unclear goals. In contrast, only half of the manager-mayors had experienced little to no adverse effects. This suggests that the political mayors are in a much stronger position in their chief executive role than the manager-mayors. Similar results have also been demonstrated in other studies, such as in the 2006 study of European mayors, which showed that strong mayors (executive or directly elected) rated their personal influence higher 
than did other types of mayors (Magnier 2006). There are three possible explanations for this difference. The first explanation, following the example of the 2006 European mayor study, is that Icelandic political mayors have more discrete power and thus do not experience the lack of goal setting in the same way as the manager-mayors. The second explanation suggests that size is an important factor, as political mayors are more often found in larger municipalities that are able to provide more professional support to the political mayor, while the manager-mayor is more often hired by smaller municipalities in order to provide the experience or skills that cannot be provided by other staff in the town hall (Hlynsdóttir 2016b). The third and final explanation is that the political mayors may be more reluctant to admit to vague goal setting as they are at the very heart of the goal-setting process.

Budgeting is the most common policy-making process at the Icelandic local level, and most other decision making is based on budgeting. The work on the budget plan usually takes place in the autumn in Iceland. In general, mayors are deeply involved in the budgeting process, but there is a qualitative difference in their involvement. The difference is both related to the size of the municipalities and the type of mayoral position. Manager-mayors who had been employed by smaller municipalities of fewer than 2,500 residents as well as by larger municipalities pointed out that there were considerable differences in the workload and responsibilities between the smaller and larger types of municipality. The main issue cited was the number of staff members: 'Here I have more staff, I am more involved in developing the ideas, but not calculating everything myself'. (Manager-mayor)

The most common procedures for councils to set the course in the budgeting process are either through manifestos or the coalition agreement of the majority parties in the council. There is considerable variation in how easy it is to integrate ideas and issues from these documents into the policy process. Based on an analysis of online manifestos issued by the Independence Party (the party that runs most often for council at the local level) for the 2014 local elections, several conclusions were made. Firstly, manifestos tend to be a mixture of vague platforms such as 'all children should have the best conditions possible for their education' and concrete issues such as 'free oatmeal porridge for all school children'. Secondly, the situation is further complicated by the mixing of issues that the party in question would like to do and those they are definitely going to do. A third complicating factor is that the manifestos often address issues that are of importance to the local community but are not the responsibility of local governance, such as rural road infrastructure or health care.

It is therefore not surprising that the importance of manifestos varies from one community to another. Overall, the manager-mayors in the larger municipalities reported having considered the manifesto more often or having integrated it into planning. One manager-mayor described a very detailed integration of the manifesto, the coalition agreement and majority decision making. 
I made a plan for the election term (four years) based on the manifesto, decision making of the majority and committee discussions. Then the staff and I prioritise and make a project list for each winter. Then it is my job to implement these issues. (Manager-mayor)

There were several such detailed accounts of how problems and ideas of the council majority are integrated and applied. These cases were, however, a significant minority, and most mayors did not report such a structured approach to policy making. Although mayors of both types had experienced negative effects because of the lack of goal setting on the behalf of the council, the manager-mayors were more direct and sometimes even critical of council members. The core of this criticism is demonstrated nicely in the words of a manager-mayor who stated that 'The largest flaw of local authorities is that council members are always doing things; they never have any plans' (manager-mayor). This suggests a culture of short-term decision-making within Icelandic local councils similar to that identified by Leach and Wilson (2002) in their study. This leads us to the issue of strategic vision and who is influencing the process of agenda setting at the Icelandic local level.

\section{Policy making at the local level: a strategic vision}

There are various actors within the local government system that participate in decision making at the local level. Members of the council, department heads and committee leaders are all in positions that hold some formal power. There may, however, never be an actualisation of that power. Therefore, it has in many ways become common to see success in decision making being equated to power (Lukes 2005). Consequently, when analysing decision-making at the local level, the perceived influence of various actors is an important indicator of actual influence patterns (Denters 2006). Respondents were asked to estimate the influence of different actors over local decision making where one was low influence and five was high influence.

Table 3. How influential are political and administrative leaders?

\begin{tabular}{lrrrrrrr}
\hline & 1 & 2 & 3 & 4 & 5 & $N$ & Average (1-5) \\
\hline Political Mayor & 0 & 0 & $2(4 \%)$ & $17(32 \%)$ & $35(65 \%)$ & $54(100 \%)$ & 4.65 \\
Manager-mayor & $1(2 \%)$ & 0 & $15(26 \%)$ & $29(51 \%)$ & $12(21 \%)$ & $57(100 \%)$ & 3.89 \\
Council leader & 0 & $2(3 \%)$ & $6(10 \%)$ & $23(37 \%)$ & $31(50 \%)$ & $62(100 \%)$ & 4.34 \\
Leader of executive board & 0 & $1(2 \%)$ & $1(2 \%)$ & $16(38 \%)$ & $24(57 \%)$ & $42(100 \%)$ & 4.47 \\
\hline
\end{tabular}

The findings in Table 3 reveal the importance of political leadership or, more precisely, executive political leadership that is in line with the findings of the 2006 study of European mayors (Denters 2006). The Icelandic political mayor was perceived as by far 
the most influential leader, with 97 per cent ranking him/her as high or very high, followed by the leader of the executive board with 95 per cent and the council leader with 87 per cent. What is interesting in this is that the manager-mayors ranked the perceived influence of all the political leaders (political mayor, leader of the council and leader of the executive board) higher than the political mayors ranked political leaders. As an example, 84 per cent of manager-mayors ranked political mayors as having very high influence, as compared to 77 per cent of political mayors. In the case of the council leader, 58 per cent of manager-mayors ranked them very high in influence, in contrast to 29 per cent of political mayors. Thirdly, in the case of the leader of the executive board, 67 per cent of manager-mayors ranked this position as having a high influence, in contrast to 33 per cent of political mayors. This discrepancy may be explained by structural differences, as the political mayor is usually the chief political leader, while in the case of the manager-mayor political leadership is vested in the council leader or the leader of the executive board. On average, the political leader had the highest score, with 4.65, followed by the leader of the executive board and the council leader. The manager-mayor had the lowest score, with the average score of just 3.89 .

Table 4. How influential is the council and administrative staff?

\begin{tabular}{lccccccc}
\hline & 1 & 2 & 3 & 4 & 5 & $N$ & Average (1-5) \\
Committee leaders & 0 & $6(8 \%)$ & $40(56 \%)$ & $24(33 \%)$ & $2(3 \%)$ & $72(100 \%)$ & 3.31 \\
Department heads & 0 & $4(10 \%)$ & $30(44 \%)$ & $30(44 \%)$ & $1(2 \%) 0$ & $68(100 \%)$ & 3.38 \\
Council majority & 0 & $1(2 \%)$ & $1(2 \%)$ & $10(18 \%)$ & $43(78 \%)$ & $55(100 \%)$ & 4.70 \\
Council minority & $1(2 \%)$ & $13(24 \%)$ & $26(47 \%)$ & $13(24 \%)$ & $2(4 \%)$ & $55(100 \%)$ & 3.09 \\
Individuals in council & $2(3 \%)$ & $4(6 \%)$ & $40(56 \%)$ & $24(33 \%)$ & $2(3 \%)$ & $72(100 \%)$ & 3.30 \\
\hline
\end{tabular}

The effects of local government structure are evident in Table 4, which shows that the council majority was estimated as being the most influential decision maker at the local level, with a score of 4.70 . This is in strong contrast to the council minority, which was perceived as being the least influential decision-maker at the local level, with a score of just 3.09. Moreover, in the case of the influence of the minority in the council, the political mayors estimated the influence of the minority as substantially higher than the manager-mayors did. As an example, 30 per cent of manager-mayors perceived the minority as having no influence or very little influence in local decision making, compared to 13 per cent of the political mayors. The reasons for this are not entirely clear. It is possible that manager-mayors underestimate the influence of the minority. European research has shown that councillors with executive responsibilities perceive their influence over decision making as much higher than those council members who have no such responsibilities (Getimis \& Hlepas 2013). Members of the minority in Icelandic local councils, in general, have limited executive responsibilities, which might explain why they are perceived to have little influence. Furthermore, the political mayors perceived the influence of the council minority as much higher than did the manager-mayors. 
These differences may be explained by the fact that political mayors do not experience conflict within the council to the same extent as the manager-mayors do, which might lead them to overestimate the influence of the minority in the council. However, there is only marginal information available on the power plays carried out within Icelandic local councils, and little is known about how council minorities perceive their influence. Nevertheless, manager-mayors and political mayors perceive the status of the council minority in very different ways.

As mentioned above, manager-mayors ranked the perceived influence of political mayors substantially higher than did the political mayors themselves. In a similar manner, the manager-mayors also estimated their own perceived influence as substantially higher than the political mayors did. As an example, 73 per cent of manager-mayors ranked themselves as having potentially high or very high influence in decision making in the local authority, as compared to 67 per cent of political mayors. As one managermayor pointed out during his interview, their potential power can be enormous.

I am fully conscious that in praxis I could be the most influential politician of them all. I could get whatever I want. These are influences and power I do not wish for. The power can be enormous, the more so, the smaller the municipality, not to speak of when individuals have great knowledge and are influential individuals. (Manager-mayor)

Although there are differences in how manager-mayors and political mayors perceived the potential influence of the aforementioned players, the overall conclusion is that there is a high emphasis on political leadership. Individuals with political connections, such as members of the council majority or committee and board leaders, are thus thought to be more influential than high-ranking officials within the administration or members of the council minority. External actors are rarely considered to be influential over decision making, with the notable exception of Icelandic regional associations and to some extent the cooperation boards. Weak partisan power is thus expressed in the lack of influence of local members of parliament (MPs) and party leaders. This may come as a surprise, as the close ties between local MPs and their communities is a wellknown feature of the Icelandic political system (Kristinsson 2015). Despite this fact, it seems that even though MPs are often suspected of distributing favours to their constituencies, Icelandic mayors do not perceive local MPs as having a significant influence on municipal decision making. Thus, there is a strong emphasis on local political leadership, but that leadership is concentrated in the majority of the council and executive board. Committee leaders do not seem to carry as much weight, which shows their weak position within the system. The reason for this may lie within the fact that the power of the committee leader is vested in a particular committee (Aars 2009). Committee leaders may not be able to extend their influence over the boundaries of their respective committees. The overall findings of this section are in line with findings from a European study (Plüss \& Kübler 2013) on local councillors where local politicians were identified 
as the most influential followed by the leader of the administration and administrative staff. Similar to the Icelandic findings, external actors were seen as having only marginal influence when it comes to agenda setting in comparison with the political and administrative leadership.

\section{Policy making at the local level: strategic responses}

As pointed out earlier in this paper there is a tendency in Icelandic public policy making to approach issues when they arise and policy often seems to happen haphazardly rather than with planning and foresight (Sigurgeirsdóttir 2006; Sigurgeirsdóttir 2005). By establishing that various political leaders are highly influential in council decision making, it becomes obvious that as political leadership is concentrated in the council and executive board, the individuals that sit on the council are crucial when it comes to long-term decision making. One experienced manager-mayor stated this clearly:

I have had councils where I had no worries about the future; these were very active individuals who had clear visions of where they were heading. Perhaps as I grow older in the position I see more clearly what needs to be done and thus I am becoming more dominating in my role. (Manager-mayor)

This manager-mayor describes a significant variation in political leadership among the council members. There is an overall consensus that setting a clear vision for the municipality, envisioning the future of the area and developing strategic direction are important tasks of political leadership (Hambleton 2004). When such vision is lacking, the leadership or management of the municipality becomes problematic. As pointed out earlier many manager-mayors felt that the council members' lack of political leadership had made their job difficult. Most of the manager-mayors who felt they needed to take initiative in the policy process had experienced this lack of political leadership.

It is no secret that the chief executive pushes the decision making forward at least for some issues. Here the politicians have tried to get together occasionally, too seldom, but at least they have met and discussed all the issues and attempted to set some goals. (Managermayor)

The manager-mayor cited above was recounting a situation in which there was a complete lack of long-term strategy. A political mayor from a small municipality admitted that the situation was problematic: 'I think it is possible to say that at least for a while, we have been looking at the short term too much'. There were cases in which councils initiated detailed and strategic long-term policy making. Such instances were, however, rare and more often found in larger municipalities with more than 2,500 inhabitants.

The council committee system has often been criticised for being slow and unorgan- 
ised (Larsen 2005). Many manager-mayors discussed the weaknesses of the Icelandic committee system: 'The main problem with this kind of administration is the amateurism. There are so many amateurs'. The Icelandic council-committee system is based on council members who work part time. The councils are also small in comparison to those in other Nordic countries. Icelandic council members are, therefore, more involved in implementation processes than their Nordic counterparts (Kristinsson 2014). As was described earlier, most Icelandic municipalities are very small, and have a limited number of core administrative staff. Expert knowledge is thus often brought into the administration through the manager-mayor (or political mayor) or an externally purchased service. One manager-mayor described the situation in the following manner:

Sadly, I think the administration is too weak. This municipality has developed its administration in a way that is full of quangos and various cooperation projects, things that the mayor has no say over. These are scattered independent agencies with their board and more or less own decision-making authority. This makes my work very complicated and does not fit my organisation chart. (Manager-mayor)

This manager-mayor felt that $\mathrm{s} /$ he lacked authority over the administration. Thus, the administration did not function properly and did not provide the central office with the support it needed. Several of the manager-mayors described similar situations of unclear hierarchies within the local government system as well as difficulties within the governance process, especially in the various cooperation schemes. The problems were then intensified because of the amateurism in the system. In several cases amalgamation was suggested as a possible solution to this problem.

The positive side of the amalgamation would be that we might be able to bring more professionalism into these committees. There should be initiative and policy making but most of the time there is none, it is just for gossip because the council members do what they like despite different ideas coming from the committee. (Manager-mayor)

As was evident from Table 4, the council and its leaders are relatively powerful, while the committee leaders are less influential. The quotation above shows that the position of the committee is often problematic. The committee members are often not equipped for the decision making that is expected of them. Moreover, their advice and decisions are often ignored by the council. This suggests similar to other studies (Plüss \& Kübler 2013) that councillors with no executive responsibilities or the so-called backbenchers have little influence in the decision making process. There is, however, limited research available on the Icelandic committee system, which makes it difficult to generalise based on these findings.

The above discussion has revealed that policy making in Icelandic local government 
is often a response to a pressing situation. Matters that arise in such situations tend to be immediate and concrete, such as the closure of a fish processing plant, local lobbying for the construction of a road tunnel or the implementation of a fishing quota. One manager-mayor described the effects of such reactive policy making: 'My feeling is that what cries for a strategy that is where they are strategic, while the issues that are not as pressing fall behind' (manager-mayor). This suggests a tendency for strategic response to be reactive rather than proactive.

\section{Discussion}

At the beginning of this paper two main questions were put forward on the issue of leadership within local government policy making and the capacity of the local administration. This discussion opens with the latter issue, namely 'what conclusions may be drawn about the administrative capacity of Icelandic local governance?'

Overall, the analysis shows that the capacity of the Icelandic local administration measured in number of specialised staff is relatively low. There is a notable difference between municipalities with fewer than 2,500 residents versus those with more than 2,500 residents. Municipalities with more than 2,500 residents demonstrated a more robust administration as they were able to have more specialised staff. Furthermore, they often employed several individuals with similar skillsets. Another indicator of weak capacity in local administration was the level of fragmentation that is capacity was not concentrated in specific areas but divided between various actors at different levels. As an example, both types of mayors often need to rely on external actors for professional advice and support, such as the Local Government Association or committees within the inter-municipal cooperation scheme. This suggests that although the simple structure of the local administration are often highly flexible and responsive (Randma-Liiv 2002; Mintzberg 1983) there is very little hierarchy at the Icelandic local level, and the division of labour is often unclear. There is also a profound lack of specialised or supporting staff in the local administration. However, it must be emphasised that these findings are not based on cross-country comparison but on a single case analysis; therefore, no conclusions can be made on the administrative capacity in relation to other countries. Nevertheless, the findings suggest that the Icelandic local administration may not always be equipped to provide other branches of local government with the support they need.

This leads us to the other question this paper attempts to answer: who is leading the task of developing strategic and policy direction at the Icelandic local level? The results show that the position of the leading politicians as in leaders of the council, executive board and a political mayor is strong when it comes to influencing strategic decision making at the local level. Yet many manager-mayors reported having to step in or take the initiative in goal setting and long-term policy making. These findings show there is an intense interaction between politics and administration within Icelandic local governments similar to previous research (Stocker and Thompson-Fawcett 2014; Svara 1990). Moreover, the findings also show that manager-mayors are able, when requested, to enter the political arena. Nevertheless, the findings reveal that there is a lack of long-term 
strategic thinking, and policy is often conducted in an unstructured and reactive mode. This is in line with earlier findings that showed that the Icelandic public administration is less disciplined and professional than would be preferred in a modern administration (Sigurgeirsdóttir 2006; Sigurgeirsdóttir 2005; Kristinsson 1994).

When these findings are discussed in relation to the laymen system on which the Icelandic council-committee system is based, there are clear signs of problems. First, as the system is based on the work of amateur politicians it relies on a strong and knowledgeable administration. Thus when there is a high turnover in the council combined with low administrative capacity it becomes difficult to accumulate and build upon previous knowledge. Second, this may lead to a situation where both the council and the administration become dependent on the manager-mayor as the 'one with all the knowledge'. The third and last point is that this creates a system that is not sustainable as it relies too heavily on individuals and individual knowledge and not on the capacity of the system itself. As more tasks and decision making power are being delegated to the local level, these problems are becoming more and more visible.

Therefore, in order to be able to estimate more precisely the administrative capacity of Icelandic local authorities, further research is needed on the division of labour between the council, local leaders and the local administration.

\section{Notes}

1 A survey on the level of inter municipal cooperation was recently conducted by the University of Akureyri Research Centre. Please see:http://www.rha.is/static/files/Rannsoknir/2016/samstarf_ sveitarfelaga_lokaskyrsla.pdf. for further information

2 Data for this study was a part of the Ph.D. project, The Icelandic mayor: A comparative analysis of political and administrative leadership roles at the Icelandic local government level. The author is grateful to the University of Iceland Research Fund for a grant rewarded to the Ph.D. research project.

3 Union des Dirigeant Territoriaux de L'Europe.

4 See also Hlynsdóttir, Eva Marín (2016). Professionalism among Icelandic Mayors: Job Postings, Experience and Education as Determinants of Professionalism at the Icelandic Local Level. Icelandic Review of Politics and Administration Vol 12, Issue 1 (23-46).

5 Article 11 in the Local Government Act no. 138/2011 made some changes to the number of council members. Subsequently, municipalities with fewer than 2,000 residents have 5-7 members; those with between 2,000-9,999 residents have 7-11 members; those with between 10,000-49,999 residents have 11-15 members; those with between 50,000-99,999 residents have 15-23 members; and those with more than 100,000 residents have 23-31 members. The capital of Iceland, Reykjavík, was the only municipality that needed to make changes based on the new definition. However, these changes were postponed during the election for the 2014-2018 term.

6 The exception to the rule is found in the 1982-1986 term. During that time, Reykjavík's city council had 21 councillors. The left-orientated majority in power in the council from 1978-1982 changed the number of councillors, but the council majority of the Independence Party changed it back.

7 All tables are based on the authors compilation unless otherwise stated

\section{References}

Aars, J. (2009). "Immune to Reform? The Nordic Mayor", in H. Reynaert, K. Steyvers, P. Delwit, and J.-B. Pilet (eds.), Local Political Leadership in Europe: Town Chief, City Boss or Loco President (pp. 307-34). Brugge: Vanden Broele. 
Andersson, L. and Mouritzen, P. E. (1998). "Technical Appendix" in K. K. Klausen and A. Magnier (eds.), The Anonymous Leader: Appointed CEOs in Western Local Government (pp. 285-312). Odense: Odense University Press.

Árnason, V., Nordal, S. and Ástgeirsdóttir, K. (2010). "Siðferði og starfshættir í tengslum við fall bankanna 2008" in P. Hreinsson, S. Benediktsdóttir and T. Gunnarsson (eds.), Rannsóknarskýrsla Alpingis, vol. 8. Reykjavík: Rannsóknarnefnd Alpingis. https://www.rna.is/media/skjol/RNABindi8. pdf.

Bäck, H., Heinelt, H. and Magnier, A. (2006). The European Mayor: Political Leaders in the Changing Context of Local Democracy. Wiesbaden: VS Verlag für Sozialwissenschaften.

Baldersheim, H. and Rose, L. E. (2010). "Territorial Choice: Rescaling Governance in European States" in H. Baldersheim and L. E Rose (eds.), Territorial Choice: The Politics of Boundaries and Borders (pp. 1-20). Palgrave Macmillan.

Bergström, T., Gianoli, A. and Rao, N. (2012). "Strong Leadership and Local Democracy: Rivals or Potential Allies?”, in L. Schaap and H. Daemen (eds.), Renewal in European Local Democracies: Puzzles, Dilemmas and Options (pp. 119-43). Wiesbaden: VS Verlag für Sozialwissenschaften.

Bergström, T., Magnusson, H. and Ramberg, U. (2008). “Through a Glass Darkly: Leadership Complexity in Swedish Local Government", Local Government Studies 34 (2), 203-20.

Berry, J. (2002). "Validity and Reliability Issues in Elite Interviewing", Political Science and Politics 35 (4), 679-82.

Collinson, D. (2011). "Critical Leadership Studies”, in A. Bryman, D. Collinson, K. Grint, B. Jackson, and M. Uhl-Bien (eds.), The Sage Handbook of Leadership (pp. 181-94). Sage Publications.

Dahl, R. A. and Tufte, E. R. (1973). Size and Democracy. Stanford: Stanford University Press.

Demir, T. (2009). "Politics and Administration: Three Schools, Three Approaches, and Three Suggestions", Administrative Theory \& Praxis 31 (4), 503-32.

Demir, T. and Reddick, C. G. (2012). "Understanding Shared Roles in Policy and Administration: An Empirical Study of Council-Manager Relations”, Public Administration Review 72 (4), 526-36.

Denters, B. (2006). "Duo or Duel? The Relations between Mayors and Councils in Democratic Local Government", in H. Bäck, H. Heinelt, and A. Magnier (eds.), The European Mayor: Political Leaders in the Changing Context of Local Democracy (pp. 271-85). Wiesbaden: VS Verlag für Sozialwissenschaften.

Denters, B., Goldsmith, M., Ladner, A., Mouritzen, P. E. and Rose, L. R. (2014). Size and Local Democracy. Edward Elgar Publishing Ltd.

Eythórsson, G. T. (1999). “Iceland”, in M. Betty, W. Linder, R. Nabholz, and C. Heierli (eds.), Democracy and Local Governance: Nine Empirical Studies. Bern: University of Bern.

Eythórsson, G. T. (2003). "Af smáum sveitahreppum og stöndugum kaupstöðum: Um próun sveitarstjórnarstigsins á Íslandi”, in Afmaliskvedja til Háskóla Íslands. Reykjavík: Bókaútgáfan Hólar.

Eythórsson, G. T. (2014). "Sameining sveitarfélaga á Íslandi i 70 ár. Röksemdir sameiningarsinna og andstæðinga [Efficiency, Capacity and Democratic Deficits. Arguments for and Against Municipal Amalgamations in Iceland for 70 Years]", Icelandic Review of Politics \& Administration 10 (1), 143-68. http://www.irpa.is/article/view/1326.

Eythórsson, G. T., Jóhannesson, H. and Hlynsdóttir, E. M. (2002). "Skagafjörður”, in G. T. Eythorsson and H. Jóhannesson (eds.), Sameining sveitarfélaga: Ábrif og afleidingar rannsókn á sjö sveitarélögum (pp. 148-83). Akureyri: Rannsóknastofun Háskólans á Akureyri.

Farazmand, A. (2004). "Innovation in Strategic Human Resource Management: Building Capacity in the Age of Globalization”, Public Organization Review 4 (1), 3-24. doi:10.1023/B:PORJ.0000015649.54219. b7.

Frederickson, G. H., and Smith, K. B. (2003). The Public Administration Theory Primer. Westview Press.

Getimis, P. and Hlepas, N-K. (2013). "Municipal Councillors as Interest Mediators: Roles, Perceptions and Enactment", in B. Egner, D. Sweeting, and P.-J. Klok (eds.), Local Councillors in Europe (pp. 13960). Wiesbaden: Springer Vs. 


\section{STJÓRNSÝSLA}

Getimis, P. and Hlepas, N-K. (2006). "Aspects of Leadership Styles: An Interaction of Context and Personalities", in H. Bäck, H. Heinelt, and A. Magnier (eds.), The European Mayor: Political Leaders in the Changing Context of Local Democracy (pp. 177-200). Wiesbaden: VS Verlag für Sozialwissenschaften.

Hagstofa Íslands (2010). “Local Government Elections 29 May 2010”, Hagtíðindi, no. May, 1-48. https:// hagstofa.is/lisalib/getfile.aspx?ItemID=11577.

Hagstofa Íslands (2015). "Local Government Elections 31 May 2014”, Hagtídindi, no. November, 1-48. file:///C:/Users/eva/Downloads/download (5).pdf.

Hambleton, R. (2004). "Leading Localities. Rethinking the Agenda", in M. Haus, H. Heinelt, and M. Stewart (eds.), Urban Governance and Democracy (pp. 190-213). Routledge.

Hlynsdóttir, E. M. (2015). “Ordførermakt eller rådmannsmakt: Lokalpolitisk lederskap på Island”, in Lokalpolitisk. lederskap i Norden, N. Aarsæther and K. H Mikalsen (eds.), (pp. 69-87). Oslo: Gyldendal Akademisk.

Hlynsdóttir, E. M. (2016a). "Leading the Locality: Icelandic Local Government Leadership Dilemma", Lex Localis-Journal of Local Self-Government 14 (4), 807-26.

Hlynsdóttir, E. M. (2016b). "Professionalism among Icelandic Mayors: Job Postings, Experience and Education as Determinants of Professionalism at the Icelandic Local Level", Icelandic Review of Politics \& Administration 12 (1), 1-22. doi:http://dx.doi.org/10.13177/irpa.a.2016.12.1.1.

Jacobsen, D. I. (2009). Administrasjonens makt-om forbolded mellom politik og administrasjon. $4^{\text {th }}$ ed. Bergen: Fagbokforlaget.

King, G., Keohane, R. O. and Verba, S. (1994). Designing Social Inquiry: Scientific Inference in Qualitative Research. New Jersey: Princeton University Press.

Kjær, U. and Mouritzen, P. E. (2003). Kommunstorrelse and lokalt demokrati. Odense: Syddansk Universitetsforlag.

Kristinsson, G. H. (1994). Embattismenn og stjórnmálamenn: Skipulag og vinnubrögd i islenskeri stjórnsyislu. Reykjavík: Heimskringla.

Kristinsson, G. H. (2001). Staðbundin stjórnmál: Markmið og árangur sveitarfélaga. Reykjavík: Háskólaútgáfan.

Kristinsson, G. H. (2014). Hin mörgu andlit lýdraðis: Dátttaka og vald á sveitarstjórnarstiginu. Reykjavík: Háskólaútgáfan.

Kristinsson, G. H. (2015). "Political Control and Perceptions of Corruption in Icelandic Local Government", Icelandic Review of Politics \& Administration 11 (1), 1-18. http://www.irpa.is/article/ view/a.2014.10.1.1/pdf.

Kuhlmann, S. and Wollmann, S. (2014). Introduction to Comparative Public Administration: Administrative Systems and Reforms in Europe. Cheltenham: Edward Elgar Publishing Ltd.

Larsen, H. O. (2005). "Transforming Political Leadership: Models, Trends and Reforms", in R. Berg and N. Rao (eds.), Transforming Local Political Leadership (pp. 195-211). Palgrave Macmillan.

Leach, S. and Wilson, D. (2000). Local Political Leadership. Policy Press.

Littig, B. (2009). "Interviewing the Elite-Interviewing experts: Is There a Difference?", in A. Bogner, B. Littig, and W. Menz (eds.), Interviewing Experts (pp. 98-116). Palgrave Macmillan.

Lukes, S. (2005). "Power and the Battle for Hearts and Minds", Millennium - Journal of International Studies 33 (3), 477-93. doi:10.1177/03058298050330031201.

Lundtorp, S. (2000). "Kommunersbæredygtighed-stordrift, demokrati og kommunalt samarbejde", http:// www.velferdarraduneyti.is/media/greinasafn/Lundtorp_2000a.pdf.

Magnier, A. (2006). "Strong Mayors?”, in H. Bäck, H. Heinelt, and A. Magnier (eds.), The European Mayor: Political Leaders in the Changing Context of Local Democracy (pp. 353-76). Wiesbaden: VS Verlag für Sozialwissenschaften.

Mintzberg, H. (1983). Structure in Fives: Designing Effective Organizations. New Jersey: Prentice Hall.

Mouritzen, P. E. and Svara, J. H. (2002). Leadership at the Apex: Politicians and Administrators in Western Local Governments. Pittsburgh: Pittsburgh University Press. 
Newton, K. (1982). "Is Small Really so Beautiful? Is Big Really so Ugly? Size, Effectiveness, and Democracy in Local Government", Political Studies 30, 190-206.

Northouse, P. G. (2013). Leadership: Theory and Practice. $6^{\text {th }}$ ed. Los Angeles: Sage Publications.

Odendahl, T. and Shaw, E. M. (2002). "Interviewing Elites", in J. F Gubrium and J. A. Holstein (eds.), Handbook of Interview Research: Context and Methodology (pp. 299-316). Thousand Oaks: Sage Publications.

Parry, K. W. and Bryman, A. (2006). "Leadership in Organizations", in S. R. Clegg, C. Hardy, T. Lawrence and W. R. Nord (eds.), The Sage Handbook of Organizational Studies (pp. 447-68). Sage Publications.

Peele, G. (2005). “Leadership and Politics: A Case for a Closer Relationship?”, Leadership 1 (2), 187-204.

Plüss, L. and Kübler, D. (2013). "Coordinating Community Governance? Local Councillors in Different Governance Network Arrangements", in B. Egner, D. Sweeting, and P.-J. Klok (eds.), Local Councillors in Europe (pp. 203-19) Wiesbaden: Springer Vs.

Polidano, C. (2000). "Measuring Public Sector Capacity", World Development 28 (5), 805-22. doi:10.1016/ S0305-750X(99)00158-8.

Ragnarsson, R. (2003). “Samvinna sveitarfélaga á Íslandi: Valkostur við sameiningu?”, MA thesis, University of Iceland.

Randma-Liiv, T. (2002). "Small States and Bureaucracy: Challenges for Public Administration." Trames 6 (4), 374-89.

Richards, D. (1996). "Elite Interviewing: Approaches and Pitfalls", Politics 16 (3), 199-204.

Sigurgeirsdóttir, S. (2005). "Health Policy and Hospital Mergers: How the Impossible became Possible." London School of Economics. http://etheses.lse.ac.uk/461/1/Sigurgeirsd\%C3\%B3ttir.pdf.

Sigurgeirsdóttir, S. (2006). "Straumar, stjórnleysi og stefnurek: Hvað er til ráða?” Icelandic Review of Politics \& Administration 2 (1). http://www.irpa.is/article/view/888/pdf_31.

Skrá yfir kjörna aðal-og varamenn í sveitarstjórnum 1994-1998 og starfsmenn sveitarfélaga (1994). Reykjavík: Samband íslenskra sveitarfélaga.

Stocker, N. and Thompson-Fawcett, M. (2014). “'It's Not Like Never-the-Twain-Shall-Meet': Politician - Staff Relationship Structures in Local Government" Local Government Studies 40 (5), 791-808. doi:1 0.1080/03003930.2014.887563.

Stone, C. N. (1993). "Urban Regimes and the Capacity to Govern: A Political Economy Approach." Journal of Urban Affairs 15 (1), 1-28.

Svara, J. H. (1990). Official Leadership in the City: Patterns of Conflict and Cooperation. Oxford University Press.

Verhelst, T., Reynaert, H. and Steyvers, K. (2013). "Political Recruitment and Career Development of Local Councillors in Europe", in B. Egner, D. Sweeting, and P.-J. Klok (eds.), Local Councillors in Europe (pp. 27-50). Wiesbaden: Springer Vs.

Vetter, A. and Kersting, N. (2003). "Democracy Versus Efficiency? Comparing Local Government Reforms Accross Europe", in N. Kersting and A. Vetter (eds.), Reforming Local Government in Europe: Closing the Gap between Democracy and Efficiency (pp. 11-28). Opladen: Leske+Budrich.

Wollmann, H. (2004). "Urban Leadership in German Local Politics: The Rise, Role and Performance of the Directly Elected (Chief Executive) Mayor", International Journal of Urban and Regional Research 28 (March), 150-65.

Zhang, Y. and Feiock, R. C. (2009). "City Managers' Policy Leadership in Council-Manager Cities", Journal of Public Administration Research and Theory 20, 461-76. 